\title{
The Roles of Finland and Norway at the Birth of NATO
}

(2012)

\author{
Scott Benting \\ Portland State University \\ scott.benting@gmail.com
}

The period between the end of World War II and the signing of the North Atlantic Treaty was fraught with intrigue. It was the beginning of the Cold War, as tension rose between the Soviet Union in the East, and the United States in the West. It was also a time of regional pacts unlike what had been in place prior to World War II. The primary difference was the inclusion of the United States in security pacts that were centered on regions outside the Western Hemisphere. In his Farewell Address of 1796, President George Washington counseled against the joining of permanent alliances, a path the United States followed for 150 years. However, with the end of World War II and the Soviet activities in European political spheres, the United States left that path of non-entangling alliances.

It was a time of change for other countries in Europe as well, especially the Nordic countries. These five countries - Norway, Denmark, Sweden, Finland, and Iceland - usually remained out of European politics, seldom on the radar of the Great Powers of Europe. However, after World War II the geographic position of the Nordic countries brought them into the sights of the major powers. Britain and the United States looked at these countries as potential members of regional security pacts that would help contain the Soviet sphere of influence during regional alliance discussions from 1945 to 1948 . The Soviet Union looked at the Nordic region, especially Finland on its western border, as an area to keep free from Western influence.

The North Atlantic Treaty (NAT) was signed on 4 April 1949, and was a monumental moment in the histories of the Nordic countries. A regional security pact, the Treaty included West and North European countries, the United States, and Canada. Its origins were a result of concerns about the expansion of the Soviet Union's sphere of influence in Eastern Europe after World War II, with many countries "falling" to Communism - both willingly and unwillingly. There was also the Soviet objective for access to the Atlantic Ocean, for which it had three routes from Soviet ports: the Turkish Straits between the Black and Mediterranean Seas; the Gulf of Finland and Baltic Sea; and around the north part of Norway into the North Sea. Soviet expansion led to discussions within the American government 
regarding ways to contain the Soviet sphere of influence, and these initial sparks for containment were fanned by many diplomatic reports in 1946-1948, including reports regarding the Nordic countries.

Historically, the geographic location of the Nordic countries put them out of the main sphere of interest of the European powers, which lasted through World War I. With the onset of World War II and the expanding Soviet sphere after the war, however, the strategic value of the Nordic region increased immensely. During the period after World War II, the Nordic region swung into the crosshairs of regional pact diplomacy. This was due in great part to Soviet activity in Eastern Europe outside the Nordic region, including the communist coup in Czechoslovakia and communist party activity in other European country elections in 1948. Ultimately, it was the Soviet influence in events that involved Finland and Norway that brought this region into a position viewed as critical to the success of the North Atlantic pact. What transpired in the Nordic region before 1949, and what was feared might transpire if the Soviets were not contained, helped to heat up the United States diplomatic endeavors in pushing for, and signing, an Atlantic regional pact that included Norway.

It is likely that the Soviet invasion of Finland and subsequent Winter War in November 1939 opened the door for the belligerent countries to make a race for northern Europe at the start of World War II. ${ }^{1}$ The German presence in the Nordic region during the War started with its 1940 invasions of Norway and Denmark. Britain preemptively occupied Iceland in 1940 before British troops departed the island for the Northern Africa campaign (Ingebritsen 2006: 78-79). ${ }^{2}$ Sweden remained neutral through the war. Finland became the only Nordic country to actively cooperate with Germany. This cooperation, however, was due to Finland's desire to remove the Soviet forces that invaded Finland on 30 November 1939.

In August 1938, the Soviets approached the Finnish government about the possibility of German troops landing in Finland as a prelude to a German invasion of the Soviet Union. Soviet assistance was offered to repel such landings, yet Finland refused the offer, noting that the Soviet proposal would violate Finland's policy of neutrality, which was not acceptable (Tanner 1957: 5-10). ${ }^{3}$ The Nazi-Soviet Pact of 23 August 1939 placed Finland (along with the Baltic States of Estonia, Latvia, and Lithuania) in the Soviet sphere of influence; however, it did not assuage the Soviets' concerns about the German government and Hitler's anti-Communist policy. The

\footnotetext{
${ }^{1}$ This idea is discussed briefly by Martti Häikiö (1983: 73)

2 The Icelandic government signed an agreement with the United States on 1 July 1941, whereby the US committed troops to defend Icelandic territory.

${ }^{3}$ First published in Finnish in 1950, this book offers an in-depth discussion of the Winter War of 1939-1940 by the man who was the Finnish Foreign Minister during the war.
} 
Finnish government was summoned on 5 October 1939 to send a representative to Moscow to discuss unspecified political questions. Finland sent State Councilor Juho K. Paasikivi to Moscow, and on 12 October he learned that Soviet Premier Joseph Stalin viewed the security of the Gulf of Finland from German forces as vital to the Soviet Union. The Soviets demanded a strip of land in the Karelian Isthmus, the fortified island of Koivisto, the Hanko peninsula on the southwest tip of Finland, and a section of the Petsamo area in the Arctic. For the 2,700 square kilometers of land requested by the Soviet government, 5,500 square kilometers was offered to Finland in eastern Karelia (Singleton 1989: 124; Tanner 1957: 21-28). The Finnish government was split on how to proceed with the Soviets, and talks between the two countries broke off in early November.

On 26 November 1939, an incident was created to give the Soviets a pretext to invade Finland. The Soviets alleged that Finnish artillery fired across the border at Soviet troops near Mainila. Diplomatic relations were broken off with the Helsinki government; the invasion of Finland started on 30 November 1939. The first Finnish town occupied was Terijoki on the Karelian Isthmus, where a puppet government (the Finnish Democratic Republic) was set up under O.V. Kuusinen, who the Soviet government claimed had requested Soviet assistance. The Helsinki government requested the assistance of the League of Nations regarding the Soviet invasion of Finland. The Soviet response included comments that there was no conflict between Finland and the Soviet Union, and that Soviet assistance was requested by the Finnish Democratic Government to avoid a possible civil war in Finland at the hands of the former Finnish rulers. The League of Nations did not accept the Soviet explanation and expelled the Soviets from League membership on 14 December 1939 (Tanner 1957: 105-109).

The resistance of Finland to the Soviet invasion was more than anyone expected, especially as they received no effective outside help. The Finns were superb fighters, holding off large Soviet columns with handfuls of soldiers. That initial success was due to their tenacity, their skills in skiing quickly around their opponents, and their ability to lie underground like hibernating animals and stay warm with stoves that burned wood without sparks or smoke. The Soviets, on the other hand, fought both the tenacious Finns and the sub-Arctic freezing temperatures (Ingebritsen 2006: 78). On 20 January 1940, Winston Churchill expressed his admiration of the Finns' tenacity in a BBC broadcast, stating, "Only Finland, superb, nay sublime in the jaws of peril, Finland shows what free men can do. They have exposed, for all the world to see, the military incapacity of the Red Army:" (Singleton 1989: 124). Peace came to Finland on 12 March 1940, ending a war it did not start. The terms of peace gave the Soviet Union a large area of Finnish land including the Karelian Isthmus, Lake Ladoga, and a large section of the Fisherman's Peninsula in the Petsamo area of northern Finland (Singleton 1989: 122-126). 
June 1941 saw the start of German military operations against the Soviet Union. Those operations included maneuvers east through Finland in its attack on the Soviet Union. Hitler used the term im Bunde to describe the relationship between Germany and Finland in the operation. Allied countries interpreted the meaning as "in alliance," while the Finnish government's translation was "side by side" as they still wanted to guard their neutrality (Manninen 1983: 149-151). Finland did not wish to be seen as a participant in the war with Germany; they just wanted to safeguard their territory from potential Soviet aggression that could be an extension of the Winter War.

Although Finland maintained a neutral attitude in the face of Hitler's comments, on 25 June 1941 Soviet air units attacked Finland to destroy airfields (Manninen 1983: 151). Throughout the Continuation War, ${ }^{4}$ Finland was determined to maintain the sympathy of the Western powers and stated its neutrality in the war between Britain and Germany. On 2 August 1941 Britain declared Finland to be under enemy occupation. In September and October 1941, the Soviet Union asked Britain to declare war on Finland; however, they refused the Soviet request. Sweden and the United States regarded Finland with goodwill and advised Britain not to declare war on Finland. The concern in Britain was that a declaration would push Finland into the arms of Germany. Instead, both Britain and the United States sent notes to Finland asking the Finns to halt their advance into Soviet territory and to maintain a position that did not go beyond the 1939 border. The Finns did not trust the Soviets and felt the cessation of military operations would be dangerous (Manninen 1983: 165-166). The Continuation War lasted until September 1944 when it was obvious the Soviets had the upper hand in the fighting in Finland. A peace settlement was signed between the Soviet Union and Finland which included moving their common border back to the 1940 location, Finland's cession of Petsamo in the north and the area around Lake Ladoga in the southeast to the Soviets, the requirement of the Finnish military to disarm German forces located within the borders of Finland, and Finland's agreement to pay a war indemnity of $\$ 300$ million within a six-year period (Nokleby 1983: 286). Through all of this, Finland was able to remain independent from the Soviet Union (Ingebritsen 2006: 79; Amundsen 1990: 35),-albeit an independence that covered the fact that Finland still had to take heed of Soviet foreign policy.

One example of Finland's bending to Soviet policy was Finland's response to the Marshall Plan. On 5 June 1947, United States Secretary of State George C. Marshall announced the State Department's plan for European economic recovery at Harvard University. Marshall noted decreasing confidence by Europeans in European

\footnotetext{
${ }^{4}$ So noted as it was seen as a continuation of the Winter War between Finland and the Soviet Union.
} 
currencies, and how the normal trade between the farms and cities had dwindled to the point where farmers were not planting all of their fields. For such circumstances to continue would eventually hurt the American economy, creating the need for the United States to do what it could to foster the return of normal economic health to the world. To such an end, it was up to the Europeans to get together and take the initiative in drafting a program to get back on their economic feet. Marshall also noted that while the plan was not aimed against any specific countries, any countries or political parties that perpetuated "human misery in order to profit therefrom politically or otherwise" would be opposed by the United States (Foreign Relations of the United States, hereafter FRUS, 1947: 3: 237-239). ${ }^{5}$ The Marshall Plan was broadcast to the world, and the United States put the offer on the table for economic help in Europe.

Britain, France, and the Soviet Union held discussions on the plan later that month. The meetings broke up on 3 July 1947 when the three parties failed to reach any agreements regarding possible American aid. During the last meeting, Soviet Foreign Minister Vyacheslav Molotov said their failure to agree would cause the British and French to be responsible for splitting Europe into two groups, and returned home. French Foreign Secretary Georges Bidault repudiated Molotov's comments and said it was the Soviet Union that would divide Europe (FRUS, 1947, 3: 306). ${ }^{6}$ After the Soviets departed from economic aid discussions, Britain and France sent invitations to twenty-two European countries to attend a conference in Paris to discuss the American aid. Finland wanted to participate in the Paris conference, and was optimistic when the Soviets met with Britain and France to discuss the plan. The Finns were in a tough position, facing both reconstruction from the war and the requirement of reparations payments to the Soviets. With funds going out in large quantities, Finland eagerly viewed the Marshall Plan as a way to stem the tide. However, when the Soviets pulled out of the planning process, they threatened the Finns by commenting that Finnish participation would be viewed as a hostile act towards the Soviet Union. Finland turned down its invitation to the Paris conference on 11 July 1947. However, in its official communiqué there was no doubt that the decision was not taken freely, stating, "Finland's position as a state has not yet been established in the form of a permanent peace treaty" (Hanhimäki 1997: 23; Korobochkin 1995: 191).

In April 1948, Finland's ties to the Soviet sphere were tightened when it agreed to the Finnish-Soviet treaty of Friendship, Cooperation and Mutual Assistance (FCMA), also called a non-aggression pact. The treaty called for each country to come to the aid of the other should they be attacked by Germany - or its allies. For the Soviet Union, this was a guarantee that the West could not launch an

\footnotetext{
${ }^{5}$ Press Release Issued by the Department of State, 4 June 1947.

${ }^{6}$ The Ambassador in the United Kingdom (Douglas) to the Sec/State, 3 July 1947.
} 
attack against it through Finland. For Finland, the agreement to the treaty guaranteed that it would remain a liberal democracy even though it was adjacent the Soviet Union. The Treaty also tightened the economic dependency of Finland on the Soviet Union. By 1948, like most countries bordering the Soviet Union, Finland was regionally and economically tied to the Soviets, although it was one of the few countries that remained democratic instead of becoming communist.

Norway also bordered the Soviet Union, and was strategically located along the Soviet Union's northern route to the Atlantic Ocean from its open water bases in the north. In March 1948, reports surfaced about a possible pact being offered by the Soviet Union to Norway, based on the Finnish model. This threat to Norway, and by it a threat to the North Atlantic countries, made Norwegian security a higher priority in the long-range planning of the United States and Britain. Although talks of a North Atlantic pact had begun, and Norway was clearly included in the list of countries to invite, it was deemed too early to tell the Norwegians about the pact. The United States had to find a way to reassure the Norwegian government and ensure they remained firm against any Soviet offerings without revealing the current North Atlantic discussions (Reid 1977: 206). In a telegram sent to the American embassy in Oslo, the United States offered its support for Norway (FRUS 1948: 3: 51-52) ${ }^{7}$ :

If Soviet demands are made on Norway, in our opinion it is imperative that Norway adamantly resist such demands and pressure. Events in Czechoslovakia and elsewhere demonstrate futility of any other course. Soviet demands on Turkey and Iran were resolutely and successfully resisted by those countries. The American Government supported both Turkey and Iran in resisting Soviet demands.

Norwegian Foreign Minister Halvard Lange noted the Norwegians would reject any Soviet-Norwegian pact proposals (Reid 1977: 207).

At the same time, in 1948 the Scandinavian countries (Sweden, Denmark, and Norway) dusted off ideas of focusing on their common interests in the north and began talks of a Scandinavian Defense Union (SDU). The Scandinavians viewed themselves as situated between two superpowers: the United States and the Soviet Union. The logical option was to form a union separate from the two powers to show the world that Scandinavia was not showing favor to either country. Norway, Sweden, and Denmark entered the negotiations with specific ideas of what they envisioned in a defense union, ideas that could be traced to the specific experiences of each country during World War II. The German invasions of Norway and Denmark in 1940 left strong memories of occupation. Sweden remained neutral

${ }^{7}$ Secretary of State to Embassy in Oslo, 12 March 1948. 
during the war, although it was possible to view Sweden's neutrality as conditional: Germany controlled the access from the Baltic Sea to the Atlantic Ocean, thus controlling Swedish ports, and Sweden conducted trade with the Germans.

Sweden contacted Norway and Denmark in May 1948 to discuss a Scandinavian Defense Union. The proposal was initiated by Swedish Foreign Minister Östen Undén, who was concerned about Western and Soviet influence on Sweden. Undén wanted to maintain relations with both sides, and he felt the only way to succeed was a regional pact formed under the UN framework to show both sides that the Nordic region was not taking sides. His primary concern was the possibility of Norway's drifting to the West, which would leave Sweden alone between East and West. Undén viewed a link between the Scandinavian countries that was not associated with a Western pact as the best hope for neutrality in the North. The inclusion of Denmark in the SDU discussions was purely for political and psychological reasons, as he viewed its geographical position in Europe as indefensible (Aalders 1990: 127, 133).

The proposal of a neutral Scandinavia was a concern to American and West European governments. Prior to President Truman's meeting with Swedish Prince Bertil and Sven Dahlman of the Swedish Foreign Office, Secretary of State Marshall asked the President to inform them of the concern of the American government about the Swedish proposal for neutrality. Marshall felt a neutral Scandinavia would be too weak to resist an aggressive Soviet expansion (FRUS 1948: 3: 134). ${ }^{8}$ A week later Marshall contacted the American Embassy in Sweden to inform them that members of Britain and France desired the participation of the Scandinavian countries in discussions of a western union; however, they believed the Swedes would not abandon their neutrality (FRUS 1948: 3: 135). ${ }^{9}$

Discussions between the three Scandinavian countries began with Sweden set for a neutral stance and Norway pushing for ties between the SDU and the West. While Undén wanted no ties to the East or West, Norwegian Foreign Minister Lange entered the talks with the goal of moving the Swedes from their neutral position to one recognizing a need for ties with the West. Lange informed American Ambassador Bay of that stance as early as 7 July 1948 (FRUS 1948: 3: 160-163). ${ }^{10}$ As the talks progressed, the differences between Norway and Sweden remained a constant. Norway argued for an SDU with an opening to the West or possible Atlantic pact membership; Sweden refused to abandon its policy of strict neutrality. The Norwegian government believed its security issues were best solved in cooperation with the West, while the Swedes believed that the West would come to the

\footnotetext{
${ }^{8}$ Memorandum by the Sec/St to President Truman, 3 June 1948.

${ }^{9}$ The Sec/St to the Embassy in Sweden, 10 June 1948.

10 The Ambassador in Norway (Bay) to the Sec/St, 7 July 1948.
} 
defense of a neutral Scandinavia if it were attacked (Greve 1963: 13; Aalders 1990: 151). Potential drafts of the SDU pact also included a requirement that the mutual defense of Scandinavia be based on attacks upon "home soil" and not "outlying" areas. That meant that an attack on Svalbard (Norway) or Greenland (Denmark) would not obligate Sweden to defend the attacked territory, nor would it be obliged to assist if Norwegian or Danish troops were attacked while stationed in Germany (FRUS 1949: 4: 69). ${ }^{11}$ The last SDU meeting occurred in Oslo on 29 - 30 January 1949, and included the presentation of a Norwegian proposal of guidelines for a joint Scandinavian approach to the Western powers. The guidelines included a provision whereby each SDU member could request the assistance of outside powers, if attacked. The proposal was rejected by Sweden, closing the door on a potential Scandinavian pact (Riste 1991: 135). As February 1949 began, Sweden would remain hopeful that SDU talks could open up again, and that the Norwegians would reconsider their position. For Norway, however, the door was open to consider joining the North Atlantic pact being discussed by the Western powers, and to bring Denmark with it.

American security planning continued to place a high value on the Nordic countries by the end of 1948. During the SDU discussions the National Security Council (NSC) published a report detailing the importance of Scandinavia to the security interests of the United States. NSC 28/1, published 3 September 1948, described Scandinavia as strategically important to both the United States and the Soviet Union. Should the Soviets dominate Scandinavia, they would have advanced air, missile, and submarine bases which would move their bomb line west and threaten Allied operations in the North Atlantic. Direct Soviet actions against one or more of the Scandinavian countries were deemed their chief threat, especially as all three had agreed not to sign any non-aggression pacts with the Soviet Union (NSC 28/1, 1948: $1-3)$.

The report noted an importance of the island possessions of both Denmark and Norway in the "cold war." Denmark's possession of Greenland and the island's strategic importance were well known in American strategic circles. The inclusion of Norway in the report, and noting it as having important islands, was somewhat new. The report observed that the geographic positions of Svalbard (named Spitzbergen in the report) and Bear Island made them able to provide advanced air and naval bases, a "Northern end" to an air defense system, and a strong point to dominate the sea lanes to ice-free Soviet ports in the north. The Soviet consulate for Svalbard was reestablished in January 1948, and reports indicated the Soviets built airstrips presumably for mining operations, although there were sites conducive for heavy

${ }^{11}$ Memorandum of Conversation, by the Counselor of the Department of State (Bohlen), 8 February 1949. 
bomber runways (NSC 28/1 1948: 4-6). The final conclusion was to strengthen the alignment of Denmark and Norway with the West, which for Norway would make it less likely that its islands would be utilized by the Soviet Union.

By the end of 1948, seven countries, including the United States and Great Britain, were discussing negotiations for a North Atlantic treaty (FRUS 1948: 3: 343). ${ }^{12}$ On 29 December 1948, Norwegian Ambassador Wilhelm Munthe de Morgenstierne approached John Hickerson, Director of the U.S. Office of Foreign European Affairs, with a request for more details on the North Atlantic Treaty. The request came in an aide-mémoire from Norwegian Foreign Minister Lange, who wanted the information during the SDU discussions. To the Americans, the request was badly timed, as the United States was not ready to discuss the treaty with the countries identified to be contacted for inclusion. Nevertheless, Hickerson assured Morgenstierne he would do his best to answer the Norwegian questions. Specific questions posed by Lange included duration of the pact, if defense material could be obtained on lenient financial terms, if military equipment could be of British design as that was the primary source of its current possessions, and obligations on Norway as a member (FRUS 1948: 3: 344-346). ${ }^{13}$ The position of the United States towards assistance of members of a neutral bloc like the proposed SDU was that they were a low priority (Greve 1963: 11-12). With limited funds and materials available, the Vandenberg Resolution (11 June 1948) placed a priority of assistance to countries and regional groupings that indicated an intention to cooperate in security arrangements with the United States or members of the Brussels Treaty. ${ }^{14}$ For the Norwegian government, it was the position of the United States on assistance to countries in a neutral bloc that was key to how the Norwegian's position themselves during the SDU discussions.

Hickerson met with Morgenstierne on 31 December 1948 to discuss his reply to Lange's request. The furnishing of military equipment by any party would not be implied by the conclusion of the treaty, although Hickerson believed legislation to transfer materials to foreign governments would be introduced and prioritized, based

\footnotetext{
${ }^{12}$ Report of the International Working Group to the Ambassadors' Committee, 24 December 1948.

${ }^{13}$ Memorandum of Conversation, by the Director of the Office of European Affairs (Hickerson), 29 December 1948.

14 While noted by Greve in Norway and NATO, he quoted from the Vandenberg Resolution a statement I could not confirm in Senate Resolution 239 (Vandenberg Resolution, 11 June 1948, FRUS, 1948, 3:135-136). This comment is actually supported in the conclusion section of NSC 28/1, where the position of the United States, as envisaged by the Resolution, gives preference in assistance by placing a neutral pact (specifically mentioning Sweden) below those countries cooperating "with the U.S. or Brussels Treaty signatories" (NSC 28/1, "A Report to the President by the National Security Council on the Position of the United States with Respect to Scandinavia" dated 3 September 1948, pp. 7-8).
} 
on which countries were under collective defense agreements with the United States. That was also Hickerson's response to the Norwegian request about gaining materials from Britain, and he told Morgenstierne to ask the British Government about military supplies. As for the question of bases on the soils of member countries, that question would not be raised with Norway at that time (FRUS 1948: 3: 348-351). ${ }^{15}$

January 1949 was a key month for the United States and the Scandinavian countries with regards to the ongoing regional pact (SDU and NAT) negotiations. John Hickerson and Acting Secretary of State Robert Lovett, supported by Senator Vandenberg and the military, handled the security question for the American State Department during the NAT talks (Lundestad 1980: 293). On 14 January 1949 Lovett sent a memorandum to the three Scandinavian countries and Britain noting the American concern with a neutral SDU. "We favor Scand defense Pact provided its members are not impeded thereby from entering larger regional pact. Scand group alone clearly would not have enough strength to protect its members against aggression" (FRUS 1949: 4: 27). ${ }^{16}$ That viewpoint was in line with the Norwegian desire to have closer ties with the West as part of a Scandinavian pact. The Swedes refused to move from their stance of strict neutrality, and the Norwegians refused to agree with the Swedish stance. The Swedes continued to hold out hope for renewed SDU discussions into February, but those discussions never occurred.

On 7 February 1949, Norwegian Foreign Minister Lange met with Secretary of State Dean Acheson. During the meeting Lange stated that he did not believe a neutral Scandinavian bloc could provide any degree of security for its members without "help from the western democracies in peacetime and in war," which he believed was an intention of the Atlantic Pact. Lange had already prepared the Norwegian Government to discuss the question of Norway's joining the NAT discussions, and wanted the United States to be aware of that situation (FRUS 1949: 4: 66-67). ${ }^{17}$

Lange believed the Soviet Union was more of a political threat than a military one. He told a group of Norwegian and American officials that the Soviets would only push their positions as far as they could short of starting a war. If Norway were in a neutral pact, then it would be possible that Soviet military bases would be placed closer to the Norwegian border than their current positions. If Norway joined a pact where the Soviets knew the consequences of an attack on Norway included actions by the Western Powers, their base positions would remain in place. Lange favored

\footnotetext{
${ }^{15}$ Memorandum of Conversation, by the Director of the Office of European Affairs (Hickerson), 31 December 1948.

16 The Acting Sec/St to the Embassy in Norway, 14 January 1949.

${ }^{17}$ Memorandum of Conversation, by the Sec/St, 7 February 1949. Also present at the meeting were Norwegian Ambassador Morgenstierne, Norwegian Labor Party Leader Oscar Torp, John Hickerson, and American Department of State Counselor Charles Bohlen.
} 
drawing a line "beyond which the Soviets cannot advance without getting into trouble with all the Western countries" (FRUS 1949: 4: 70-71). ${ }^{18}$ For another month the Norwegian government held discussions about the North Atlantic pact, a neutral SDU, and an offer of a non-aggression pact by the Soviet Union (Greve 1963: 32-33), ${ }^{19}$ before finally focusing on becoming signatories of the North Atlantic Treaty.

Both Finland and Norway bordered the Soviet Union, yet Finland's experience with the Soviets was significantly different from that of Norway. The 1939 Winter War with the Soviet Union showed the aggressive nature of the Soviets and their desire to expand at the expense of their neighbors. Finland used Germany as a resource to push back at the Soviets during World War II, yet they were also able to maintain their democratic government in the face of losing to the Soviets. Soviet pressure kept Finland from participating in the Marshall Plan, which would have provided muchneeded economic assistance that Finland could not get elsewhere. Also, the nonaggression pact offered by the Soviets in 1948 cemented the economic tie of Finland to the Soviets, although it continued to let Finland keep its democratic government.

The experiences of Finland with the Soviet Union were on the minds of the diplomats of Norway and the West in 1948. Concerns that Norway could be offered a non-aggression pact with the Soviets similar to the Soviet pact with Finland created concern throughout the West. Sweden feared being alone between East and West when it started talks for a Scandinavian Defense Union with Norway and Denmark. While the Swedish model called for a neutral pact, Norway felt a need to be able to connect with the West. Neutrality was a failed position during World War II when the Germans occupied Norway, and there was concern about the possibility of a similar invasion by the Soviet Union. Also, having had a wartime "Atlantic policy," it was natural for the Norwegians to join a North Atlantic security pact (Lundestad 1980: 319-323; Riste 1985: 131-133). The United States and Britain also feared Soviet activity in Norway that could resemble Soviet activity in Finland and Eastern Europe, and worked to ensure Norway was included in the NAT. The Soviets did not want Norway connected with the West for many reasons, including Norway's geographic position along the Soviet northern route to the Atlantic, thereby offering the Norwegians a non-aggression pact as a means of good faith; the Norwegians refused. In the face of Soviet expansion in Europe and fears of being cut off from historical trade allies in the West, on 4 April 1949, Norway joined other traditionally neutral countries including the United States, Denmark, and Iceland, as original signatories of the North Atlantic Treaty.

\footnotetext{
18 Memorandum of Conversation, by the Counselor of the Department of State (Bohlen), 8 February 1949.

19 Text of note to the Norwegian Government, 5 February 1949.
} 


\section{References}

Aalders, Gerard. (1990) The Failure of the Scandinavian Defence Union, 19481949. Scandinavian Journal of History vol.15, pp. 125-153.

Amundsen, Kirsten. (1990) Soviet Strategic Interests in the North. New York: St.

Martin's Press.

Greve, Tim. (1963) Norway and NATO. Oslo: Royal Ministry of Foreign Affairs. Häikiö, Martti. (1983) The Race for Northern Europe, September 1939-June 1940. In Nissen (1983).

Hanhimäki, Jussi M. (1997) Scandinavia and the United States: An Insecure Friendship. New York, Twayne Publishers.

Ingebritsen, Christine. (2006) Scandinavia in World Politics. Oxford: Rowman \&

Littlefield Publishers, Inc.

Korobochkin. Maxim. (1995) Soviet Policy Toward Finland and Norway, 1947-

1949. Scandinavian Journal of History vol. 20, pp. 185-207.

Lundestad, Geir. (1980) America, Scandinavia, and the Cold War 1945-1949. New York: Columbia University Press.

Manninen, Ohto. (1983) Operation Barbarossa and the Nordic Countries. In Nissen (1983).

Nissen, Henrik S. (ed.). (1983) Scandinavia During The Second World War.

Minneapolis, Minnesota: The University of Minnesota Press.

Nokleby, Berit. (1983) Adjusting to Allied Victory. In Nissen (1983).

NSC 28/1. (1948) A Report to the President by the National Security Council on the Position of the United States with Respect to Scandinavia, dated 3 September 1948, Washington, D.C.

Reid, Escott. (1977) Time of Fear and Hope: The Making of the North Atlantic

Treaty, 1947-1949. Toronto: McClelland and Stewart.

Riste, Olav. (1991) Nordic Union or Western Alliance? Scandinavia at the Crossroads 1948 - 1949. In Ennio Di Nolfo (ed.), The Atlantic Pact Forty

Years Later. New York: Walter de Gruyter.

Riste, Olav. (1985) Was 1949 a Turning Point? Norway and the Western Powers 1947-1950. In Olav Riste (ed.), Western Security: The Formative Years:

European and Atlantic Defence 1947-1953. Oslo: Universitetsforlaget.

Singleton, Fred. (1989) A Short History of Finland. Cambridge: Cambridge University Press.

Tanner, Väinö. (1957) The Winter War: Finland Against Russia 1939-1940.

Stanford, CA: Stanford University Press.

U.S. Department of State. Foreign Relations of the United States (FRUS).

Diplomatic Papers. Washington, D.C.: U.S. Government Printing Office. 